\title{
THE PERPETUATION OF EXTREME POVERTY AS A FACET OF THE GLOBAL STRUCTURAL DESIGN1
}

\section{A PERPETUAÇÃO DA POBREZA EXTREMA COMO FACETA DO PROJETO ESTRUTURAL GLOBAL}

\section{FABRÍCIO JOSÉ RODRIGUES DE LEMOS}

Doutorando em Direito na Universidade Federal do Rio Grande do Sul - UFRGS (20172021). Mestre em Direito Público pela Universidade do Vale do Rio dos Sinos - Unisinos (2016). Possui graduação em Direito pela Universidade do Vale do Rio dos Sinos Unisinos (2013). Integrante do Núcleo de Direitos Humanos da Unisinos (NDH), da Latin American Studies Association (LASA) e da International Law and Politics CRN (Collaborative Research Network). Tem experiência na área de Direitos Humanos, Direito Internacional Público e Direito Civil. Professor da Faculdade de Direito - Universidade Feevale. Advogado - OAB/RS 91.595.

\section{ABSTRACT}

Objectives: The paper will try to refer to how International Law can help modify this perverse facet of global structural design (which is commonly pointed out as the source of much of the adversities that are imposed on the global poor) and thus strive to reduce inequality in a global extent, as International Law fails to guarantee that basic human needs are attained - not only in relation to food but as well as regarding health.

Methodology: In this sense, the methodology used is based on bibliographical research, as well as doctrine and articles published in specialized journals.

\footnotetext{
${ }^{1}$ This paper was presented on June $2^{\text {nd }} 2018$ at the Institute for Global Law and Policy: The Conference (Harvard Law School), in Cambridge, MA, USA. It represents the ongoing research I am conducting at the International Law program at the Federal University of Rio Grande do Sul (UFRGS) as a PhD candidate. Therefore, I would like to thank all the members of the Critical Thinking in International Economic Law panel for their questions and suggestions regarding this article.
} 
Results: The study of the conceptualization of the theory of global justice, what its objectives are and what it seeks to measure, with the conclusion that the responsibility evaluation of international institutes through the lens of a theory of global justice occurs simultaneously with the responsibility assessment of the individual at world level. They way towards a significante reduction in global inequality, therefore, is based on the protection of human rights and on the accountability of international institutions for possible violations of these same rights.

Contributions: The study raises the question in what can be considered a global condition of justice, i.e., what is the global just. This is an extremely complex issue, whatever the possible response, basic human rights should not have their guarantees affected - they must be preserved.

KEYWORDS: Global justice; international law; international economic law; responsibility.

\section{RESUMO}

Objetivos: $O$ artigo tentará referir-se a como o Direito Internacional pode ajudar a modificar essa faceta perversa do projeto estrutural global (que é comumente apontado como a fonte de muitas das adversidades que são impostas aos pobres do mundo) e, assim, esforçar-se para reduzir a desigualdade de uma maneira geral, em âmbito global, pois o Direito Internacional falha em garantir que as necessidades humanas básicas sejam atendidas - não apenas em relação aos alimentos, mas também em relação à saúde.

Metodologia: Nesse sentido, a metodologia utilizada é baseada em pesquisas bibliográficas, bem como em doutrinas e artigos publicados em periódicos especializados.

Resultados: Conclui-se do estudo da conceitualização da teoria da justiça global (quais são seus objetivos e o que ela busca mensurar), que a avaliação de responsabilidade de institutos internacionais sob as lentes de uma teoria de justiça global ocorre simultaneamente com a avaliação de responsabilidade do indivíduo em âmbito mundial. O caminho para uma redução significativa da desigualdade global, portanto, baseia-se na proteção dos direitos humanos e na responsabilização das instituições internacionais por possíveis violações desses mesmos direitos.

Contribuições: $O$ estudo levanta a questão sobre o que pode ser considerado uma condição global de justiça, ou seja, qual é o justo global. Esta é uma questão extremamente complexa; seja qual for a resposta possível, os direitos humanos básicos não devem ter suas garantias afetadas - eles devem ser preservados. 
PALAVRAS-CHAVE: Justiça global; lei internacional; direito econômico internacional; responsabilidade.

\section{INTRODUCTION}

With the progressive prestige of the major international institutions, important topics of International Law, once confined to the diplomatic discussion tables, have become part of a larger scheme of global concerns. The media, the citizens, governments and international organizations, firstly by internationalization, then by globalization, were posed with increasingly urgency to a number of issues related to global everyday life. (CRAWFORD; KOSKENNIEMI, 2012, p. 01).

However, an increasing focus of International Law gave rise, perhaps, to its greatest challenge: over the last decades, international interactions - no longer solely restricted to States, but also to international institutions, multinational corporations, national companies, non-governmental organizations, and as well and at the same scale, to individuals - have greatly altered the contemporary world and restructured global political-economic relations.

Therefore, given that, among a wide variety of legal fields, International Law is the most open to moral and philosophical contemplation, precisely because it carries, in its core, ideas about peace, social justice, freedom and rational management (KOSKENNIEMI, 2012, pp. 47-48), it is necessary to gauge the responsibility of international institutions for the changes that have taken place in the world today: to ensure the potential benefits created, in order to expand them; however, it is imperative to identify the harms of the new global structure, with the purpose of abolishing them.

The necessity of reflecting on a theory of global justice in modern philosophical thinking combined with International Law has increased the past decade: Thomas Pogge (2010, p. 10) states that, just in the early years of the present millennium, thinkers have given the subject much more attention than in the entirety of the previous century. In this manner, the Yale-based philosopher indicates that, up until World War II, the moral thought on international relations restricted itself mainly in terms of war. 
Nonetheless, in face of the atrocities carried in the 1939-1945 period, Pogge points, alongside with a broader global interdependence, the creation and strengthening of the United Nations (UN) system - and the consequent Universal Declaration of Human Rights (UDHR) -, as the beginning of the process of erosion of the Westphalian paradigm. ${ }^{2}$ The author indicates that, given that state sovereignty started to mitigate in face of the fortification and the establishing of minimum and uniform global standards for the treatment of citizens within their own countries, global or international institutions started to occupy spaces that were reserved only to national governments, acquiring some of its political functions and power. ${ }^{3}$ Pogge $(2010$, p. 10-11) adds that the development of a global justice theory is also prone to study the horrors of war, but it focus on the modifications fueled by the innovations that technology can exert within the countries respective jurisdictions.

Nancy Fraser (2008, p. 31) points out, in this sense, that there is no more space for philosophical-political thinking to focus on justice within a Westphalian perspective, mainly because of the growing interconnectivity in relations in the globalized world.

Although economic globalization has existed from the nineteenth century (BEITZ, 2005, p. 14), since the 1970s, with the emergence of new demands arising from the development of globalization in an ampler and integrating manner, philosophers and theorists have asked pressing questions about how the establishment of a post-Westphalian world modifies and broadens the moral responsibility of governments, corporations, and individuals. (POGGE, 2010, p. 11). These reflections raised several questions, of which the following stand out:

\footnotetext{
2 The Treaty of Westphalia, signed in 1648, ended the Thirty Years' War, a series of conflicts set off in continental Europe. From the consensus emerged the modern international system, with the principles of state sovereignty and nation-state, which makes the majority of authors attribute to the treaty the quality of initial landmark of international relations. (MOITA, 2012).

${ }^{3}$ Teixeira (2011, p. 143) affirms, in this matter, however, a pessimistic prognosis: 'Sovereignty understood as the principle of political organization of the State is in a process of loss of extent, intensity and capacity of control over the destiny and the purposes that serve to guide and aggregate citizens of a national State, in a way that all this process is for the benefit of the strengthening of an international legal order destined to guarantee the development of humanity and the maintenance of the worldwide peace, even though the universality of human existence and the search for the implementation of the rights that would be inherent to it end up causing more wars and, consequently, transform any idea of world peace into utopia'.
} 
Are our current global economic arrangements fair ones and if not, how should they be transformed? What responsibilities do we have to one another in a globalized, post-Westphalian world order? How should we allocate responsibilities for reducing global injustice in our world, [...]? (BROCK, 2015, p. 01).

Mathias Risse (2012, p. 03) states that globalization denotes processes that erode the political and economic importance of the nations borders and increasingly affect life opportunities through the system of rules that constitute the global order. Therefore, at the global justice field, the crucial inquiries are often posed as if the parameters of domestic justice may also apply within and/or between all societies and peoples in the world. (LANDESMAN, 2011, p. 422-423).

Hence, it was necessary to conceive a theory of justice capable to address the quarrels of actual relations in the globalized contemporary field, given that the traditional accounts of justice no longer can satisfactorily frame the problems and emergences that arise from today's interconnected world, whose requirements often surpasses States boundaries.

Nowadays, there is a growing debate on what can be considered a theory of justice that really covers different global plural conditions, i.e., a theory that can clearly establish the rights and duties of all towards all - relations between individuals, private corporations, international institutions, States.

On the other hand, there is an increase in the prestige of international institutions, which, exerting influence on the domestic policies of the States, end up interfering, incisively, in the life of individuals. Such interference may serve to avoid a dumping policy in a given hermetic economical system exposed to global market turmoil by protecting the employment and social status of domestic workers, strengthening the local economy. However, it may also serve to prevent poor people from accessing essential medicines, while protecting the rights of big pharmaceutical companies in setting global prices, most of the times too high for markets in less economically prosperous countries.

These considerations must be made in a general manner, under the bias of a theory of global justice, since, as B.S. Chimni (2007a, p. 212) indicates, there is 
currently no way to comprehend the fate of a society by dissociating it from the global collective: 'The fates of all societies have today come to be linked in ways that no longer allow any state to postulate and implement what may be termed a domestic theory of justice.'

Therefore, even though there is a strong desire to seek managerial solution to the intertwined issues on an international level, there is, under the outlook of a theory of global justice, a growing incentive towards the moralization of International Economic Law - which includes sharing responsibilities in the global field.

In this matter, relying upon bibliographical research, of both legal doctrine and published research papers, based on the premise that there is the possibility of establishing, as an ethical parameter of an ideal of a fair world, the positivation, protection and guarantee of universal Human Rights, this article intends to assert, once the responsibility of international institutions has been appraised, in which way can International Law help to change such a perverse facet of the structural global design and, consequently, strive to reduce global inequality.

\section{THE PERVERSE FACET OF THE GLOBAL STRUCTURAL DESIGN}

The world is full of injustice and inequalities. There is no need to adduce that: there is nothing new in the statement and this pronouncement leaves little - or no controversy leeway. However, as Thomas Nagel (2005, p. 113) puts it:

[...] it is much less clear what, if anything, justice on a world scale might mean, or what the hope for justice should lead us to want in the domain of international or global institutions, and in the policies of states that are in a position to affect the world order.

The international legal-economic relations are a facet of global structural design often pointed out as source of a large part of the adversities that are imposed on the global poor. In this matter, for example, given the constant interconnectivity of economic, social and political international institutions, B.S. Chimni (2004, p. 01-02), a 
well-known scholar in the field of Third World Approach to International Law - TWAIL, argues about a constitution of a nascent global state with imperialistic features - this nascent global state, he indicates, has, as its main function, the realization of '[...] the interests of transnational capital and powerful states in the international system to the disadvantage of third world states and peoples'.

The author (CHIMNI, 2007b, p. 05) denotes that this fact follows from what he denominates globalization of alienation, in which contemporary International Law promotes a notion of good life that turns self-realization and the real producers into commodities in detriment of a view that stress cooperation between producers and consumers, with ethical interactions in social life. Focusing on endless commodities and services circulation towards the benefit of consumer choice, this way of comprehending International Law explains the centrality of the World Trade Organization (WTO) in today's global life. On the other side, however, it occurs that International Law fails when it is unable to guarantee basic standard needs of humanity - regarding not only food, but also basic health -, because of the subversion of said rights to the fundamentalist logic of the market.

Sharing the concerns of the Jawaharlal Nehru University professor ${ }^{4}$, especially regarding the consequences of WTO's TRIPS Agreement (Trade Related Aspects of Intellectual Property Rights), Thomas Pogge (2010, p. 20), a Yale University philosophy professor, adduce that there has been a world standardization of intellectual property regulation - signing parties are obliged to guarantee twenty years of intellectual monopoly to the manufacturers and researchers in a wide array of innovations, including a vast quantity of medicines -, implicating in catastrophic damages to the health and life of the global poor.

The French jurist Alain Supiot (2007, p. 251, our translation) notes, also about TRIPS Agreement, that the Universal Declaration of Human Rights, proclaimed by the United Nations General Assembly in 1948, could have been '[...] interpreted in a sense

\footnotetext{
${ }^{4}$ 'Likewise, the right to health has been subverted by subjecting it to the fundamentalist logic of the market. My reference here is, of course, to the consequences flowing from the WTO TRIPS Agreement'. (CHIMNI, 2007b, p. 05).
} 
in which the property right of the pharmaceuticals companies over their patents must perish in front of the rights of populations to have access to adequate care'.

Even so, the logic of the market is stronger: such agreement has drastically diminished the chances of the poor to access more advanced medicines, given that, with the generics competition, it is estimated that the pharmaceutical companies would reduce purchase prices to a tenth of contemporary prices in a rather large amount of medicines. ${ }^{5}$ The inexistence of market competition during the patent protection period, and the lack of supply of drugs to countries economically less developed, makes it harder for the global poor to have access to medicines that prevent and fight easily treatable diseases, which, without proper medical care, depending on circumstances, can be fatal - as, in fact, millions of times per year, they are. (POGGE, 2010, p. 21). Unfortunately, this tendency of aggravation of the present status quo persists, in a perverse facet, given that it does not solely acts towards the settling of States inequalities, but it tends to perpetuate them. (STIGLITZ, 2002, p. 197). ${ }^{6}$

Interesting to note that, focusing away of injustices per se - conceding that the world is, in fact, unequal -, Pogge (2010, p. 21) intends to criticize the TRIPS Agreement in order to illustrate how can institutional moral analysis applied to the global institutional order would look like and what could it change: the present world order perpetuates global poverty in a large scale, and, since feasible changes could avoid such events, the failing in performing necessary reforms not only implicates wealthy countries on the misery but as well in the violation of the rights of the poor. (BROCK, 2015, p. 11). International institutions also share such responsibility, as it is seen in the excerpt below:

\footnotetext{
${ }^{5}$ It is important to note that Thomas Pogge is aware of the need of compensating for the costs of research and development undertaken by the pharmaceutical companies, and also in relation to their respective profits. The philosopher advocates, alongside with Noam Chomsky, Amartya Sen, Peter Singer and others influential thinkers, through the Health Impact Fund (POGGE, 2012b), a new way of encouraging the creation, research and development of new drugs, while providing access to vital medicines for the world's poorest people, thereby ensuring pharmaceutical companies fair compensation for a given period, based on the positive impact that such medicines bring to the quality of life of the persons contemplated.

6 'Today, the Fund has reversed course, putting pressure on countries, particularly developing ones, to implement more contractionary policies than these countries would choose of their own accord'. (STIGLITZ, 2002, p. 197).
} 
[...] central components of International Law systematically obstruct the aspirations of poor populations for democratic self-government, civil rights, and minimal economic sufficiency. And central international organizations, like the World Trade Organization (WTO), the International Monetary Fund (IMF) and the World Bank, are designed in ways that systematically contribute to the persistence of severe poverty. (POGGE, 2012, p. 373).

The resulting global institutional order is indisputably unjust insofar as the incidence of violence and severe poverty occurring under it is much larger than would have been the case under an alternative order, an order whose project would have given greater weight to the interests of the poorest and most vulnerable worldwide. (POGGE, 2010, p. 22).

It is important to emphasize that the eradication of extreme poverty is not enough: the existing inequality at the global level must also be tackled - pressing issues arise from injustices; not only because of poverty. The dignity of the global poor is attacked when such individuals are not recognized as persons; or it is oppressed through the process of marginalization imposed on these human beings in relation to the society in which they live. Therefore, inequality is also a great impediment to tackling poverty. (MESTRUM, 2009, p. 40-41). At the same subject, Francine Mestrum (2009, p. 41), about the globalization process, states:

Globalization could be the first historical process that gives a real and meaningful content to the concept of global community and of one universal humankind. In order for globalization to benefit everyone, inequality should be tackled with redistributional justice, with global taxes and global social protection, beyond poverty reduction. Poverty is not an individual problem, but a problem of the whole of society; it points to a biased distribution of incomes, and that is the level at which it has to be tackled. (MESTRUM, 2009, p. 41).

However, there are difficulties in changing the institutional moral paradigm, since a great number of actors benefit from global inequality - throughout what Rainer Forst calls multiple domination ${ }^{7}$-, and, considering that citizens from different countries participate in a wide range of shared practices that transcend national boundaries,

7 'It is not just that poor people lack necessary means of subsistence, it is that they are deprived of such means in situations of multiple domination: in a complex network of powers, several agencies influence the actions of others so that a number of them profit, whereas others - collectives or persons - profit very little or not at all'. (FORST, 2012, p. 247). 
economic and commercial interdependence hampers the containment of the negative aspects of these relations. (BROCK, 2009, p. 26).

B.S. Chimni (1990, p. 299) argues that International Law, even though containing structures of domination and exploitation, is not simply a tool in the hands of stronger states. In the author's conception, the foundational scheme of International Law is inserted in a paradigm of autonomy in relation to the structures of power and influence - precisely because it is a complex system of mediated practices, there is room for the demands of less economically developed countries. It concludes by pointing out that the idea of respect for International Law may have beneficial consequences for the countries and peoples of less economically developed places, even though historical processes indicate that this has not always been the case.

Therefore, Hèlene Ruiz Fabri (2012, p. 352) argues that, although there is a strong desire to seek managerial solutions to interconnected issues at the international level, there is a growing call for a moralization of International Economic Law - which includes, beyond omnipresent concepts of security, predictability and transparency, also the sharing of responsibilities in the global field.

\section{GLOBAL JUSTICE AND THE REVIEW OF THE ROLE OF INTERNATIONAL INSTITUTIONS}

Inquiries about global justice differ from those about international justice by not limiting its scope to only what States must do. They question the State system itself, while evaluating alternative mechanisms. (RISSE, 2012, p. 33). The center of attention of international justice theories - the ethical responsibility of governments - is widened towards the scope of global justice theory - i.e., the study of moral responsibilities of all members of the human kind.

In international justice, the nation or state is taken as the central entity of concern and justice among nations or states is the focus. In the domain of global justice, by contrast, theorists do not seek primarily to define justice between states or nations. Rather they drill down through the state shell and 
inquire about what justice among human beings consists in. Global justice inquiries take individual human beings as of primary concern and seek to give an account of what fairness among such agents involves. (BROCK, 2015, p. 03).

Generally speaking, a global justice theory seeks to establish what is justice in a global scale, in order to aid contemporary philosophical debate to better comprehend what is the world and what are the individual responsibilities in it. (BROCK, 2015, p. 04).

Before focusing on the question of the responsibility of international institutions and their relation to issues of global inequality, Thomas Pogge, ahead of many theorists of its time - and even before the 1993 publication of John Rawls' seminal article The Law of Peoples, which defended, for the first time in international theory, a duty of assistance among peoples -, was already fully aware that individuals have moral responsibility towards one another at global level, responsibility which becomes even more compulsory when seen in the relationship between individuals from influential countries towards the global poor: the global institutional scheme is imposed by all members on all its members - it has no optional participation.

And it is imposed on all by all; however, the imposition comes often from above, by individuals from the most influential countries. Thus, it is correct to say that institutions are created, shaped, modified and perpetuated by individuals who seek to advance their own interests: property and promises, money and markets, governments and borders, treaties and diplomacy do not occur naturally; they are all inventions of men and can therefore be modified. (POGGE, 1989, p. 276).

Since social institutions are more or less just depending on how they distribute morally significant benefits and burdens among their human participants, this causal responsibility gives rise to a moral responsibility, which is a collective responsibility for our collective role in imposing existing institutions upon, in particular, their most disadvantaged (and involuntary) participants. This responsibility may be of great moment when we find ourselves to be (advantaged) participants in an unjust institutional scheme. We have a negative duty not to collaborate in the imposition of unjust institutions; and we must then reflect upon and promote institutional reform. (POGGE, 1989, p. 276). 
It should be noted that the search for moral responsibility of the individual is not an accusatory quest or of guilty assessment: many of those collaborators of situations of injustice throughout the centuries did not have the necessary discernment to visualize the misconception in their conduct, even though that nowadays such actions are seen as acts of violation of third party rights. However, if they had the necessary discernment, such individuals would have compulsory moral responsibility to act in pursuit of institutional reforms to reverse situations of violation of rights. (POGGE, 1989, p. 278).

For this reason, Pogge's theory of global justice, with a consistency that can be traced from his earliest writings, assumes that the concern of his thesis does not revolve around accusations: it seeks to demonstrate and to bring to the discussion, through a global panoramic view, the fact that contemporary global institutional order is, as it is designed, unfair - with a strong tendency to be increasingly unequal - and that individuals, governments and corporations in the most influential countries should strive to repair this paradigm. It looks for new ways of resolving global conflicts, in order to reform current institutions, exploring new ways of acting, in order to guarantee a world with a more just structure and, thus, to ensure that the future generations may have full capacity - in an easier manner than the current generation - to achieve their objectives of good life. (POGGE, 1989, p. 278).

After this brief introduction about individual responsibilities at the global level, the pressing question of the article will be discussed: in relation to international economic institutions, there has been a shift in the scope of its activities since the 1970 s - from the guarantee of a stable international monetary system with an objective of securing world trade and growth, to a mission to aid the poorest countries, to encourage them to join international trade or to return to it. Therefore, the International Monetary Fund (IMF) began to focus on the so-called developing countries, granting them loans with interest rates below of those practiced in the international market. Since then, given that the States need access to international credit, the financial institution started to increase the number of conditions for these concessions, militating for significant changes in the institutions and the internal plan of the applying countries. 
The promotion of growth and the resolution of specific crises have become the mission of the International Monetary Fund - becoming increasingly similar to the World Bank -, which culminated, in the year 2000, in the engagement of more than sixty countries, that is, more than a third of the so-called developing countries. (MILNER, 2005, p. 836).

Thus, there is an expansion of the power of richest countries, i.e., the main International Monetary Fund and World Bank shareholders, which end up greatly influencing the domestic policy of the least economically developed countries, by imposing norms for the granting of such loans, without this raising any suspicions within the international legal system. For example, in today's world, it is easier to penalize discrimination of foreign investment and capital than to guarantee protection of migrant workers' rights. See, the World Trade Organization (WTO) has 164 members who are subject to its parameters and rules; in 2016, 181 countries signed investment protection treaties, which grant affected corporations the permission to prosecute States. However, fewer than 50 countries are committed to protecting immigrants, their human rights and their economic rights as workers. (JAHAN, 2016, p. 139).

As noted above with the reference to Stiglitz (2002, p. 197), economic power ends up perpetuating inequalities, since it serves its own interests. Delmas-Marty (2003, p. 13), in her lecture on north-american political and economic power in the rest of the world, indicates that world economic law can emerge through regional institutions that, by imposing respect for International Law, could facilitate a rebalancing not only because they constitute trade blocs, but also through the production of standards common to all.

On this topic, Delmas-Marty $(2003$, p.16) argues that there is an internationalization of the internal norms of countries of great political and economic power that, '[...] by a mimetic process, tend to align under the norms considered to be of international worth and, more often, of Anglo-Saxon origin'. In this sense, other countries must fight against this role played by Law: the '[...] idea of explicit selling of American law throughout the world', which makes possible 'without territorial occupation', and even without investing funds in economic and social development, to 
determine the cultural and economical form of other nations, leading them to the legal system that will command social organization'. (DELMAS-MARTY, 2003, p.15).

Moreover, the structural design of international institutions and the unequal evolution of global markets present many challenges to human development and the fight against inequality, mainly because there is a strong tendency, in the more prosperous segments of the world population, to concentrate capital, which, given its nature and acceptability, circulates freely, allowing the creation of legal loopholes, that are, for instance, favorable to tax evasion and also to illicit activities. In a similar matter, the creation of barriers to worker migration hampers the development of poorer countries, as orderly migration increases opportunities for human development. Migrant workers, three-quarters of whom migrate to countries with better living conditions, find chances that they would not normally have in their countries of origin in addition, migrant workers are a source of income, investment and commerce for their home countries. (JAHAN, 2016, p. 140).

It is therefore necessary to assess the responsibility of international institutions for the maintenance of the current global status quo. B.S. Chimni (2007, p. 217) calls for a principle of redistributive justice in which it is necessary to audit Economic International Law, in order to assess the impact of this legislation on the global poor for the author, there must be recognition of the primacy of international human rights law in relation to international economic laws.

\section{CONCLUSION}

As stated in the introduction, the purpose of this article is to present arguments so that the reader can reasonably argue, in a well-substantiated manner, for the need to assess accurately the responsibility of international institutions in creating - or in the maintenance of - global problems. This concern becomes especially relevant in relation to extreme poverty and inequality issues, and thus, discussion of this matter may provide additional support for International Law to change the current status quo. 
Thus, beginning with conceptualizing the theory of global justice, the article indicated, in broad terms, what the theory is about, what its objectives are and what it seeks to measure. It concluded that the responsibility evaluation of international institutions through the lens of a theory of global justice occurs simultaneously with the responsibility assessment of the individual at world level.

It is not possible to establish as a parameter for a theory of global justice solely the institution of a minimum subsistence condition for all individuals, as the humanitarians ${ }^{8}$ wish, inasmuch as can be seen from the analysis of the quote below, injustices can remain in the society, even after resolving such a problem.

Imbalances, inequalities, and injustices are also characterized when the preservation of a minimally decent and dignified life is not at stake. In that case, other criteria of justice may be used, as in the case of merit, of the will of the contracting parties, of good faith or of some utilitarian consideration (for example, the State's financial capacity). Provided that this does not affect the guarantee of basic (human) rights. (BRAGATO, 2010, p. 133, our translation).

Considering that there are problems and conflicts that affect everyone globally and for which there should be a concerted response that could lead to a situation of global justice, the question lies then in what can be considered a global condition of justice - i.e., what is the global just. This is an extremely complex issue, but as Bragato points out above, whatever the possible response, basic human rights should not have their guarantees affected - they must be preserved.

Therefore, even if the establishment of another criterion for the measurement of the global just occurs, human rights have an important role in the resolution of such a theorem. In this sense, Bragato, as can be seen in the excerpt below, when dealing

\footnotetext{
8 'Many who reject global equality as an ideal of justice still believe that there is a certain minimum of wellbeing that all should have the opportunity of achieving. We might call this view Humanitarianism. The humanitarian will support taxation and active government to make sure all in his own society have the ability to achieve a basic minimum. But he will not find anything wrong with great inequality once that minimum is met. One might, similarly, be a humanitarian about Global Justice and believe that there is a basic minimum with regard to both material needs and human rights that all people should be able to attain. Such a person would support some transfer of wealth from rich to poor countries insofar as it can help produce a basic minimum for all. But he will not care about inequality among nations once that basic minimum is reached'. (LANDESMAN, 2011, p. 423).
} 
with the subject of fair societies, indicates that, even if a philosophy of human rights lost its ability to provide answers to situations that demand justice - within the internal context or, by logical condition of Forst's ${ }^{9}$ thought - any chosen criterion must be guided by the minimum level, i.e., by human rights.

\begin{abstract}
Therefore, just are those societies that truly recognize the dignity of each one and that allow the coexistence of plurality kept at a distance from the institutionalized forums of society during modernity. But it is clear that, beyond this minimum level, which is compatible only with the guarantee of decent lives, human rights lose their ability to respond to other situations that demand justice, opening space for other criteria that are, however, guided by this minimum threshold. (BRAGATO, 2010, p. 134).
\end{abstract}

Therefore, based on the example of international economic institutions, which merely replicate the policy of their largest stockholders, influencing the imposition of their norms - and ideologies - on economically least developed countries, the aim of this article is to demonstrate the need for the responsibility assessment of international institutions in the maintenance of global status quo.

There are clear reasons, then, to assert with confidence that world structuring is organized in such a way as to harm the poorest, keeping them in a state of poverty, and helping the prosperous to remain in the position they are in - the structural design provides subsidies for capital concentration and the perpetuation of world poverty, which, as the global economy grows, multiplies inequality. Hence, the way towards a significant reduction in global inequality, therefore, is based on the protection of human rights and on the accountability of international institutions for possible violations of these same rights.

\title{
REFERENCES
}

BARRETTO, Vicente de Paulo; BRAGATO, Fernanda Frizzo. Leituras de filosofia do direito. Curitiba: Juruá Editora, 2013.

9 'There can be no global justice without internal justice, and vice versa'. (FORST, 2012, p. 250). 
BEITZ, Charles R. Cosmopolitanism and global justice. In: BROCK, Gillian. MOELLENDORF, Darrel. (Org.). Current debates on global justice. Dordrecht: Springer, 2005. p. 11-27.

- Political theory and international relations. Princeton: Princeton University Press, 1999.

. The idea of human rights. Oxford: Oxford University Press, 2009a.

Press, 2009b.

; GOODIN, Robert E. (Org.). Global basic rights. Oxford: Oxford University

BRAGATO, Fernanda. Os direitos humanos como critério de justiça nas sociedades plurais. Revista Acadêmica - Faculdade de Direito do Recife, Recife, v. LXXXII, p. 119-137, 2010.

BROCK, Gillian. Global justice. In: ZALTA, Edward. (Org.). Stanford Encyclopedia of Philosophy. Stanford, Mar. $062015 . \quad$ Available at: $<$ http://plato.stanford.edu/entries/justice-global/>. Access in: 17 may 2015.

Global justice: a cosmopolitan account. Oxford: Oxford University Press, 2009.

; BRIGHOUSE, Harry. (Org.). The political philosophy of cosmopolitanism. Cambridge: Cambridge University Press, 2005. 262 p.

; MOELLENDORF, Darrel. (Org.). Current debates on global justice. Dordrecht: Springer, 2005.

CHIMNI, Bhupinder Singh. A just world under law: a view from the South. In: American University International Law Review 22, n. 2, 2007a. p. 199-220. Available at: $<$ http://tinyurl.com/zf3vmc6>. Access in: 14 set. 2016.

International institutions today: an imperial global state in the making. In: European Journal of International Law, n. 1, vol. 15, 2004. p. 1-37. Available at: <http://tinyurl.com/jkenq5x>. Access in: 26 set. 2016.

- Legitimating the international rule of law. In: CRAWFORD, James. KOSKENNIEMI, Martti. (Org.). The Cambridge companion to International Law. Cambridge, UK: Cambridge University Press, 2012.

The past, present and future of International Law: a critical third world approach. In: Melbourne Journal of International Law, n. 27, vol. 8(2), 2007b. p. 116. Available at: <http://tinyurl.com/zogxrz4>. Access in: 26 set. 2016. 
The World Trade Organization, democracy and development: a view from the South. In: Journal of World Trade, n. 40, vol. 1, 2005. p. 5-36. Available at: <http://tinyurl.com/jsn3l8l>. Access in: 04 out. 2016.

. Third World Approaches to International Law: a manifesto. In: International Community Law Review, n. 8, 2006. p. 3-27. Available at: <http://tinyurl.com/go5bw8r>. Access in: 20 set. 2016.

CRAWFORD, James. KOSKENNIEMI, Martti. Introduction. In: CRAWFORD, James. KOSKENNIEMI, Martti. (Org.). The Cambridge companion to International Law. Cambridge, UK: Cambridge University Press, 2012. p. 01-21.

DELMAS-MARTY, Mireille. Três desafios para um direito mundial. Rio de Janeiro: Lumen Juris, 2003. $205 \mathrm{p}$.

FABRI, Hèlene Ruiz. Regulating trade, investment and money. In: CRAWFORD, James. KOSKENNIEMI, Martti. (Org.). The Cambridge companion to International Law. Cambridge, UK: Cambridge University Press, 2012. p. 352-372.

FORST, Rainer. Contexts of justice: political philosophy beyond liberalism and communitarianism. Berkeley: University of California Press, 2002. 346 p.

Justice, morality and power in the global context. In: POGGE, Thomas. FOLLESDAL, Andreas. (Org.). Real world justice: grounds, principles, human rights and social institutions. Dordrecht: Springer, 2005a. p. 27-36.

Polity, 2014. $216 \mathrm{p}$.

. Justification and critique: towards a critical theory of politics. Cambridge:

The right to justification: elements of a constructivism theory of justice.

New York: Columbia University Press, 2012. 351 p.

FRASER, Nancy. Escalas de justicia. Barcelona: Herder, 2008. 294 p.

JAHAN, Selim. (Ed.). Human development report. New York: United Nations Development Programme, 2016. 286 p.

KOSKENNIEMI, Martti. International Law in the world of ideas. In: CRAWFORD, James. KOSKENNIEMI, Martti. (Org.). The Cambridge companion to International Law. Cambridge, UK: Cambridge University Press, 2012. p. 47-63.

LANDESMAN, Bruce M. Global justice. In: CHATTERJEE, Deen K. (Org.). Encyclopedia of Global Justice. New York: Springer, 2011. p. 421-424. 
MESTRUM, Francine. Why we have to fight global income inequality. In: KOHONEN, Matti; MESTRUM, Francine. (Ed.). Tax justice - putting global inequality on the agenda. London: Pluto Press, 2009. p. 25-44.

MILNER, Helen. Globalization, Development, and International Institutions: Normative and Positive Perspectives. Perspective on Politics, [S.I.], v. 3, n. 4, p. 833-854, 2005. Available at: <http://faculty.georgetown.edu/jrv24/milner_05.pdf>. Access in: 09 abr. 2017.

MOITA, Luís. Uma releitura crítica do consenso em torno do sistema vestefaliano. Ejournal of International Relations, [S.I.], 3, n. 2, 2012. Available at: $<$ http://tinyurl.com/qzlpcqh>. Access in: 09 set. 2015.

NAGEL, Thomas. The problem of Global Justice. In: Philosophy and public affairs 33, n. 2, 2005. p. 113-147. Available at: <http://tinyurl.com/ond56ad>. Access in: 14 jun. 2015.

ONU. Declaração universal dos direitos humanos. 1948. Available at: <http://www.ohchr.org/EN/UDHR/Documents/UDHR_Translations/por.pdf>. Access in: 12 jul. 2015.

POGGE, Thomas. (Org.). Freedom from poverty as a human right: who owes what to the very poor. New York: Oxford University Press, 2007a. 406 p.

'Assisting the global poor'. In: CHATTERJEE, Deen K. The ethics of assistance: morality and the distant needy. Cambridge, UK: Cambridge University Press, 2004a. Available at: <http://tinyurl.com/zzsudzo>. Access in: 15 dez. 2015.

Are we violating the Human Right's of the world's poor? In: Yale Human Rights and Development Journal, n. 2, vol. 14, 2014. p. 1-33. Available at: <http://tinyurl.com/goq8a9u>. Access in: 26 set. 2015.

Divided against itself: aspiration and reality of International Law. In: CRAWFORD, James. KOSKENNIEMI, Martti. (Org.). The Cambridge companion to International Law. Cambridge, UK: Cambridge University Press, 2012. p. 373-397.

Ending poverty. 2012a. 1 post (20 min 46 s). Postado em: 2012. Available at: <http://tinyurl.com/grcbatc>. Access in: 23 jan. 2015.

FOLLESDAL, Andreas. (Org.). Real world justice: grounds, principles, human rights and social institutions. Dordrecht: Springer, 2005.

John Rawls: His life and theory of justice. New York: Oxford University Press, 2007b. 
2010.

Politics as usual: What lies behind the pro-poor rhetoric. Sttaford: Polity,

. Priorities of global justice. Metaphilosophy, [S.I.], v. 32, n. 1/2, p. 06-24, 2001. Available at: <http://tinyurl.com/qe8628y>. Access in: 16 jun. 2015.

. Real world justice. In: BROCK, Gillian; MOELLENDORF, Darrel. (Org.). Current debates on global justice. Dordrecht: Springer, 2005b. p. 29-53.

Realizing Rawls. Ithaca: Cornell University Press, 1989. 296 p.

The Health Impact Fund. 2012b. 1 post (1h 25 min 47 s). Postado em: 2012. Available at: <http://tinyurl.com/zddb5ru>. Access in: 30 jan. 2015.

. The incoherence between Rawls's theories of justice. Fordham Law Review, [S.I.], 72, 2004b. p. 1739-1759. Available at: <http://tinyurl.com/h57akll>. Access in: 29 dez. 2015.

. The international significance of human rights. The Journal of Ethics, [S.I.], 4, n. 1/2, 2000. p. 45-69. Available at: <http://www.jstor.org/stable/25115635>. Access in: 27 jan. 2016.

. World poverty and human rights. Ethics \& International Affairs, [S.I.], 19, n. 1, 2005a. p. 01-07. Available at: <http://tinyurl.com/qanu4zz>. Access in: 16 jun. 2015.

. World poverty and human rights: cosmopolitan responsibilities and reforms. Cambridge: Polity, 2002. 284 p.

RAWLS, John. Law of peoples and the idea of public reason revisited. Cambridge: Harvard University Press, 1999b. 207 p.

. Law of peoples. In: SHUTE, Stephen; HURLEY, Susan. (Org.). On human rights: the Oxford amnesty lectures 1993. New York: HarperCollins Publishers, 1993. p. 36-68.

RISSE, Mathias. On global justice. Princeton: Princeton University Press, 2012. 465 p.

SUPIOT, Alain. Homo juridicus: ensaio sobre a função antropológica do Direito. São Paulo: WMF Martins Fontes, 2007. 283 p.

STIGLITZ, Joseph E. Globalization and its discontents. New York: W. W. Norton \& Company, 2002. 282 p. 
TEIXEIRA, Anderson V. Teoria pluriversalista do direito internacional. São Paulo: WMF Martins Fontes, 2011. 324 p. 